\title{
Specifying the relationship between key stages of pike (Esox lucius L.) embryogenesis and coagulants used in lake recultivation
}

\author{
Adam Tański ${ }^{1}$, Małgorzata Bonisławska ${ }^{2}$, Agnieszka Tórz² ${ }^{2}$ Krzysztof Formicki ${ }^{1}$, \\ Arkadiusz Nędzarek ${ }^{2}$, Arkadiusz Drost ${ }^{2}$, Agnieszka Rybczyk ${ }^{2}$
}

\footnotetext{
${ }^{1}$ Department of Hydrobiology, Ichthyology and Biotechnology of Reproduction, West Pomeranian University of Technology Szczecin, K. Królewicza 4, 71-550 Szczecin, Poland, e-mail: adam.tanski@zut.edu.pl (corresponding author)

${ }^{2}$ Department of Aquatic Sozology, West Pomeranian University of Technology Szczecin, K. Królewicza 4, 71-550 Szczecin, Poland
}

\begin{abstract}
The study focused on the effect of iron and aluminium coagulants (PIX 113, PAX $^{\oplus} 18$ ) commonly used for purification of open waters on key stages of embryonic development of pike (Esox lucius L.). Fertilized pike roe was incubated in lake water and in water with the admixture of coagulants, applied in the concentration of $50.0 \mathrm{mg} \mathrm{dm}^{-3}$ at selected stages of embryogenesis: blastopore closure, inoculation, and the hatching of larvae. In the course of the experiment, live embryos were observed and total lengths of the larvae were measured. Simultaneously, selected hydrochemical indicators were gauged. It was discovered that coagulants had the strongest effect at the first stage of embryogenesis (the end of the process of gastrulation). At that stage the survival rate of embryos was the lowest (73.5$75.0 \%)$ and the percentage of deformities in the hatched larvae was the highest (9.7-10.0\%).
\end{abstract}

Key words: coagulant $\mathrm{PIX}^{\oplus} 113, \mathrm{PAX}^{\oplus} 18$, pike embryonic development, Lake Przybiernów

\section{Introduction}

Eutrophication of waters constitutes an enormous problem in Poland. By accelerating the ageing of lakes, it results in deteriorating environmental conditions of aquatic biotopes, and causes, among other things, oxygen deficits that lead to changes in the structures of biocenoses, affecting protected species as well as the species that are valuable from the point of view of the economy. Furthermore, the deteriorating quality of water thwarts the development of tourist infrastructure, which directly affects the economic condition of some regions.

Various methods have been applied in order to improve the condition of degraded water bodies, both biological ones, such as biomanipulation and aeration of lake waters (Podsiadłowski et al. 2008; Wesołowski et al. 2010) and very common chemical ones - the application of coagulants, for instance ones that are based on iron compounds, such as PIX 113 (water solution of iron(III) sulphate(IV)) or aluminium compounds, such as $\mathrm{PAX}^{\circledR} 18$ (water solution of polyaluminium chloride) (Pizarro et al. 1995; Gawrońska et al.
2001; Gawrońska and Brzozowska 2002; Gawrońska et al. 2002; Tandyrak et al. 2001; Tandyrak 2002).

Chemical precipitation of phosphorus in lakes achieved with the aid of coagulants results in reducing the number of biogenic compounds and thus reduces the intensity of algae development, improving water quality and inducing a decrease in water $\mathrm{pH}$ (Ito et al. 2000; Konieczny et al. 2007; Łopata et al. 2007; Piasecki and Zacharzewski 2010). As the few studies conducted so far have shown, aquatic organisms found in water bodies, such as plankton, ichthyofauna, and benthos do not remain unaffected by changes in environmental properties that are caused by the coagulants mentioned above (Lelková et al. 2008; Piasecki and Zacharzewski 2010; Bonisławska et al. 2012). According to Lelková et al. (2008), in consequence of adding $\mathrm{PAX}^{\oplus} 18$ to fish pond water, an increase was observed in the amount of nitrogen as compared to the amount of phosphorus, which resulted in the disappearance of blue-green algae Planktothrix agardhii. The study of Piasecki and Zacharzewski (2010) on the application of coagulants (PIX, PAX) for lake water treatment led to the conclusion that they contributed to increasing the 
presence of such bioindicator species as the cladoceran freshwater water flea (Daphnia magna Straus), and also to decreasing biomass increment. Such changes may have a direct effect on changes in particular links of the trophic chain. Furthermore, studies conducted by Bonisławska et al. (2012) on the influence of coagulants on the embryogenesis of pike also revealed an adverse effect on embryo survival, size of larvae and the number of occurring deformations when the coagulants were added to water directly after fertilization. It was decided, on the basis of results that had been obtained in 2012 (Bonisławska et al. 2012), to check whether the sensitivity to the impact of PIX ${ }^{\oplus} 113$ and PAX ${ }^{\circledR} 18$ was changing in the course of the embryonic development of pike. Therefore, the aim of the present study was to determine the influence of these coagulants, which are used in recultivation of water bodies, on the key stages of embryogenesis of a fish species commonly occurring in lakes, i.e. pike (Esox lucius L.). Results of the study will be helpful in determining the optimal periods of coagulant application, when their presence does not pose a threat to the wellbeing of ichthyofauna.

\section{Materials and methods}

The research was conducted in March 2013. Water used for pike roe incubation was taken from Lake Przybiernów (West Pomeranian Voivodeship). Physico-chemical properties of the lake water were examined before and after the application of PIX ${ }^{\oplus} 113$ and $\mathrm{PAX}^{\oplus} 18$ coagulants at respective stages of embryogenesis. Coagulants were applied in doses of $50.0 \mathrm{mg} \mathrm{dm}^{-3}$ and the analysis of samples containing coagulants was performed 48 hours after the application.

The hydrochemical tests were conducted according to the methodology recommended by the APHA (1995). The titrimetric methods were used to determine the overall alkalinity (hydrochloric acid to methyl orange), chloride ions (the Mohr method), the total hardness, as well as the calcium and magnesium ions (with the complexometric methods of disodium edetate to eriochrome black $\mathrm{T}$ and murexide). The particular forms of nitrogen, phosphorus, sulphates, and general iron were determined with the colorimetric methods. The UV-VIS spectrophotometer Pharo 300 Spectroquant (by Merck) was used in the colorimetric methods, measuring the absorbance at the recommended wavelengths $(\lambda)$. Nitrite nitrogen was determined with sulphanilamide $(\lambda=543 \mathrm{~nm})$; nitrate nitrogen was determined as nitrite nitrogen after reduction on the $\mathrm{Cu}-\mathrm{Cd}$ column; ammonium nitrogen was determined by indophenol blue $(\lambda=630 \mathrm{~nm})$. The total inorganic nitrogen (TIN) was calculated as the sum of nitrite nitrogen, nitrate nitrogen and ammonium nitrogen. The total nitrogen (TN) was determined as the nitrate nitrogen, after prior mineralization with potassium persulphate in an alkaline environment. The total organic nitrogen (TON) was calculated as the difference in the total nitrogen and inorganic nitrogen. The total reactive phosphorus (TRP) was determined by the ammonium molybdate and ascorbic acid as a reducing agent $(\lambda=882 \mathrm{~nm})$ method. The total phosphorus (TP) was determined in the same way as reactive phosphorus after the prior mineralization with potassium persulphate in an acidic environment. The total organic phosphorus (TOP) was calculated as a difference in the TP and TRP. Additionally, sulphates were determined with barium chloride $(\lambda=420 \mathrm{~nm})$. Total iron was determined with phenanthroline $(\lambda=$ $510 \mathrm{~nm})$. The chemical oxygen demand $\left(\mathrm{COD}_{\mathrm{Cr}}\right)$ was determined using bichromate. The total suspended solids parameter (TSS) was determined by weight, and the suspended sediment concentration (SSC), using the Imhoff funnel. The $\mathrm{pH}$ of the water was measured with the $\mathrm{pH}$-meter $\mathrm{CP}-103$ (by Elmetron), while the conductance was measured with the conductivity meter CC-101 (by Elmetron).

The physico-chemical data of the coagulants used (according to the manufacturer's specifications) are as follows: the PIX ${ }^{\oplus} 113$ is approximately $40-42 \%$ aqueous solution of sulphate (IV), and iron (III), consisting of $11.8 \pm 0.4 \%$ of the total iron and up to $1 \%$ of free sulphuric acid (VI); the $\mathrm{PAX}^{\oplus} 18$ is an aqueous solution of polyaluminium chloride containing 17.0 $\pm 0.6 \% \mathrm{Al} 2 \mathrm{O} 3$ and $20.0 \pm 2.0 \%$ of chloride ions.

The research into the course of pike embryogenesis in lake water with coagulants was conducted in a laboratory, which allowed a fixed temperature of 9.0-10.0 ${ }^{\circ} \mathrm{C}$ to be maintained. Gametes were acquired from sexually mature spawners from Lake Przybiernów. The spermatozoa (originating from four male individuals) were transported in sample tubes, whereas the eggs (originating from six female individuals) were placed in thermoses of $0.5 \mathrm{dm}^{3}$ capacity. Subsequently, gametes secured in this way were put into isothermal containers assuring constant temperature (Bonisławska et al. 2012).

The process of fertilization took place in the laboratory and the eggs were put into 7 water tanks, each 
with the capacity of $40 \mathrm{dm}^{3}$ (six experimental tanks and one control tank) filled with water from the location where pike spawning occurred naturally: Lake Przybiernów. Water in all tanks was gently aerated. Water temperature was measured daily and oscillated at around $10.0 \pm 0.5^{\circ} \mathrm{C}$. Whitened eggs were removed and counted daily: only the normally developing roe was left in the tanks.

The experiment was conducted using the coagulants PIX 113 (samples marked as “a”) and PAX 18 (samples marked as "b") in $50.0 \mathrm{mg} \mathrm{dm}{ }^{-3}$ concentration. The coagulants were sprayed over the water surface at the following stages of embryonic development: (I) the end of the process of gastrulation, i.e. development of the germinal epithelium - the stage of blastopore closure: samples 1a, 1b; (II) the appearance of pigment cells in the eyeballs of an embryo - the stage of inoculation: samples $2 \mathrm{a}, 2 \mathrm{~b}$; (III) the beginning of embryos hatching from eggs - the stage of first larvae hatching: samples $3 \mathrm{a}, 3 \mathrm{~b}$.

In the course of the experiment live observation of embryos developing in eggs was conducted. For that purpose several egg specimens were collected and observed under the microscope. The images were then saved in the format of digital photographs using the MultiScan Base v. 13.01 computer program for image analysis. Before the coagulant application, the percentage of fertilized eggs was determined on a sample of 100 eggs.

At the final stage of the experiment, i.e. during hatching, twenty pike larvae were collected from each variant, recorded and subjected to measurements. With the aid of the MultiScan Base v. 13.01. program, total body length of the larvae was measured (longitido totalis - 1.t.). The duration of the embryogenesis was expressed in degree-days $\left(\mathrm{D}^{\circ}\right)$, i.e. as the number of days of the embryogenesis multiplied by the average daily temperature. The survival rate of embryos was calculated as the percentage of hatched larvae within a group of 100 fertilized eggs, and the percentage of malformed larvae was calculated as the percentage of malformed specimens within a total number of larvae hatched in a given variant.

The results obtained were statistically elaborated using the Statistica ${ }^{\circledast}$ 9.0 PL program, applying such statistical methods as the single-factor analysis of variance (ANOVA) and the Duncan test $(p<0.05)$ in order to compare body lengths of the larvae hatched from eggs incubated in the control sample and those hatched from eggs incubated in the water that contained the PIX ${ }^{\odot} 113$ and PAX $^{\oplus} 18$ coagulants.

\section{Results}

Results of hydrochemical analysis of the water used for roe incubation are shown in Table 1.

The analysis of data obtained from the examination of respective control samples of water before the addition of respective doses of coagulants revealed slight fluctuations of the values of most physico-chemical indicators in the course of the experiment, which was confirmed by the calculated standard deviation values. Only in the case of ammonia nitrogen, reactive phosphorus and total phosphorus was it noted that their concentrations more than doubled at the stage directly preceding the beginning of hatching. The average increase in the concentrations of those indicators amounted to $0.539 \mathrm{mg} \mathrm{N} \mathrm{dm}^{-3}, 0.164 \mathrm{mg} \mathrm{P}$

Table. 1. Values of determined physico-chemical indicators (average \pm standard deviation SD) of the water used for experimental studies before adding the coagulants at respective stages of embryogenesis

\begin{tabular}{|c|c|c|c|c|c|c|c|c|c|}
\hline Conductivity & $\mathrm{pH}$ & $\begin{array}{c}\text { Total } \\
\text { alkalinity }\end{array}$ & $\begin{array}{c}\text { Total } \\
\text { hardness }\end{array}$ & $\mathrm{Ca}^{2+}$ & $\mathrm{Mg}^{2+}$ & $\mathrm{SO}_{4}^{2-}$ & $\mathrm{Cl}^{-}$ & $\mathrm{COD}_{\mathrm{Cr}}$ & TSS \\
\hline$\left[\mu \mathrm{Sm}^{-1}\right]$ & & \multicolumn{2}{|c|}{ [mval dm $\left.{ }^{-3}\right]$} & \multicolumn{4}{|c|}{$\left[\mathrm{mg} \mathrm{dm}^{-3}\right]$} & {$\left[\mathrm{mgO}_{2} \mathrm{dm}^{-3}\right]$} & {$\left[\mathrm{mg} \mathrm{dm}^{-3}\right]$} \\
\hline $\begin{array}{c}444 \\
\pm 5.70\end{array}$ & $\begin{array}{c}7.67 \\
\pm 0.12\end{array}$ & $\begin{array}{c}3.60 \\
\pm 0.07\end{array}$ & $\begin{array}{c}4.35 \\
\pm 0.15\end{array}$ & $\begin{array}{l}75.57 \\
\pm 0.77\end{array}$ & $\begin{array}{l}10.45 \\
\pm 1.26\end{array}$ & $\begin{array}{l}47.16 \\
\pm 1.97\end{array}$ & $\begin{array}{l}24.41 \\
\pm 0.89\end{array}$ & $\begin{array}{c}31.7 \\
\pm 3.90\end{array}$ & $\begin{array}{c}7.6 \\
\pm 1.70\end{array}$ \\
\hline \multicolumn{6}{|c|}{ The form of nitrogen } & \multicolumn{3}{|c|}{ The form of phosphorus } & E \\
\hline $\mathrm{N}-\mathrm{NO}_{2}^{-}$ & $\mathrm{N}-\mathrm{NO}_{3}^{-}$ & $\mathrm{N}-\mathrm{NH}_{4}{ }^{+}$ & TIN & TON & $\mathrm{TN}$ & TRP & TOP & TP & 10 \\
\hline \multicolumn{6}{|c|}{ [mg N dm$\left.{ }^{-3}\right]$} & \multicolumn{3}{|c|}{$\left[\mathrm{mg} \mathrm{P} \mathrm{dm}^{-3}\right]$} & {$\left[\mathrm{mg} \mathrm{dm}^{-3}\right]$} \\
\hline $\begin{array}{c}0.016 \\
\pm 0.003\end{array}$ & $\begin{array}{c}0.270 \\
\pm 0.082\end{array}$ & $\begin{array}{c}0.517 \\
\pm 0.321\end{array}$ & $\begin{array}{c}0.803 \\
\pm 0.298\end{array}$ & $\begin{array}{c}0.412 \\
\pm 0.088\end{array}$ & $\begin{array}{c}1.215 \\
\pm 0.356\end{array}$ & $\begin{array}{c}0.146 \\
\pm 0.148\end{array}$ & $\begin{array}{c}0.080 \\
\pm 0.023\end{array}$ & $\begin{array}{c}0.226 \\
\pm 0.166\end{array}$ & $\begin{array}{c}0.159 \\
\pm 0.004\end{array}$ \\
\hline
\end{tabular}


$\mathrm{dm}^{-3}$ and $0.215 \mathrm{mg} \mathrm{P} \mathrm{dm}^{-3}$, respectively. The effect of coagulant addition on the values of particular indicators is displayed in Table 2 and 3.

Reductions of phosphorus and organic matter content were observed after the application of both coagulants, within the range of $49.8-62.6 \%$ for TRP and $\mathrm{TP}$ and $12.4-14.7 \%$ for $\mathrm{COD}_{\mathrm{Cr}}$. Additionally, the application of the $\mathrm{PAX}^{\oplus} 18$ coagulant resulted in iron and sulphate reduction by $72.3 \%$ and $18.7 \%$ respectively. Furthermore, the application of that coagulant resulted in an increase in chloride ion concentration by $53.9 \%$. Meanwhile, the application of the PIX ${ }^{\oplus} 113$ coagulant resulted in an increase in total iron, chloride ion and sulphate ion concentrations by $122.3 \%, 7.2 \%$ and $13.6 \%$, respectively (Table 2 ). The application of the PIX 113 and PAX 18 coagulants resulted in the precipitation of suspended solids in the amounts of 3.0 and 7.5 $\mathrm{cm}^{3}$ respectively and in an increase in TSS, by 2.5 and $10.9 \mathrm{mg} \mathrm{dm}^{-3}$ respectively. Furthermore, the addition of the coagulants caused a slight drop in the $\mathrm{pH}$ value of the total water volume (an average decrease in the $\mathrm{pH}$ value equalled 0.09 for PIX 113 and 0.07 for $\mathrm{PAX}^{\oplus} 18$ ). As for the settling suspended solids (SSC), a decrease in the $\mathrm{pH}$ value was noted in comparison to the water above their layer that amounted to as much as 0.56 (for the samples with PIX ${ }^{\oplus} 13$ ) and 0.40 (for the samples with $\mathrm{PAX}^{\circledast} 18$ ) on average (Table 3 ).

The study of initial stages of embryonic development of pike (before applying the coagulants) showed that the percentage of fertilized eggs was very high and amounted to $82.0 \%$. Constant live observation of the course of pike embryogenesis did not reveal any differences regarding the pace of embryonic development in the studied variants until the time when the body of an embryo was formed $\left(110.0^{\circ} \mathrm{D}\right)$. Both in the
Table. 3. Total suspension (TSS) and suspended solids (SSS) (average \pm standard deviation) after 48 hours from the application of the doses of the respective coagulants and $\mathrm{pH}$ of the settling suspended solids

\begin{tabular}{l|c|c}
\hline Indicator & PIX ${ }^{\circledR 113}$ & PAX ${ }^{\circledR 18}$ \\
\hline SSS $\left[\mathrm{cm}^{3}\right]$ & $3.0 \pm 1.0$ & $7.5 \pm 0.8$ \\
\hline TSS $\left[\mathrm{mg} \mathrm{dm}^{-3}\right]$ & $10.10 \pm 2.65$ & $18.50 \pm 2.90$ \\
\hline $\mathrm{pH}$ & 7.02 & 7.20 \\
\hline
\end{tabular}

control sample and in the remaining samples, the embryos achieved the respective stages of embryogenesis at the equal number of degree-days (Figs 1 and 2).

In spite of that, the process of hatching did not take place simultaneously in all samples. On the twelfth day of embryogenesis, hatching began in the control sample $\left(125.0 \mathrm{D}^{\circ}\right)$ and in samples $3 \mathrm{a}$ and $3 \mathrm{~b}$. Then the coagulants were added to the latter two samples ( $3 \mathrm{a}$ and $3 \mathrm{~b}$ ) and mass hatching took place within 6 hours. Next, the hatching began in variants $1 \mathrm{a}$ and $2 \mathrm{a}$ $\left(130.0 \mathrm{D}^{\circ}\right)$. Finally, the hatching occurred in variants $1 \mathrm{~b}$ and $2 \mathrm{~b}\left(133.0 \mathrm{D}^{\circ}\right)$.

Distinct, statistically significant differences with respect to body lengths were noted while measuring the average total body length of hatched larvae from these variants (Table 4).

The longest larvae were found in the control sample and in variants $3 \mathrm{a}$ and $3 \mathrm{~b}$ (no statistically significant differences). Shorter larvae hatched from the eggs in variants $1 \mathrm{a}$ and $1 \mathrm{~b}$, as well as $2 \mathrm{a}$ and $2 \mathrm{~b}$ (Table 4). In the samples in which the coagulants were applied, the percentage of embryo survival was 5.0-8.0\% lower in comparison to the control group (Table 4). Simultaneously, in the same samples the percentage of deformed individuals that hatched from eggs exposed to the effect of PIX and PAX at the aforementioned

Table. 2. Concentrations of selected indicators (average \pm standard deviation SD) after 48 hours from the application of the coagulants and their percentage increase or decrease in comparison to the initial values

\begin{tabular}{|c|c|c|c|c|c|c|}
\hline \multirow{2}{*}{ Coagulant } & TRP & TP & $\mathrm{Fe}$ & $\mathrm{Cl}^{-}$ & $\mathrm{SO}_{4}^{-2}$ & $\mathrm{COD}_{\mathrm{Cr}}$ \\
\hline & \multicolumn{2}{|c|}{$\left[\mathrm{mg} \mathrm{P} \mathrm{dm}^{-3}\right]$} & \multicolumn{3}{|c|}{$\left[\mathrm{mg} \mathrm{dm}^{-3}\right]$} & {$\left[\mathrm{mgO}_{2} \mathrm{dm}^{-3}\right]$} \\
\hline $\mathrm{PIX}^{\circledR 113}$ & $0.035 \pm 0.012$ & $0.054 \pm 0.013$ & $0.357 \pm 0.019$ & $25.98 \pm 0.50$ & $54.67 \pm 1.36$ & $25.68 \pm 2.57$ \\
\hline $\mathrm{PAX}^{\circledR} 18$ & $0.055 \pm 0.043$ & $0.094 \pm 0.040$ & $0.044 \pm 0.004$ & $37.28 \pm 1.78$ & $37.97 \pm 2.04$ & $28.15 \pm 3.89$ \\
\hline \multicolumn{7}{|l|}{ Reduction $\%$} \\
\hline $\mathrm{PIX}^{\circledR} 113$ & $51.6 \pm 3.5$ & $62.6 \pm 2.2$ & - & - & - & $14.73 \pm 3.90$ \\
\hline $\mathrm{PAX}^{\circledR} 18$ & $56.2 \pm 3.7$ & $49.8 \pm 18.5$ & $72.3 \pm 2.5$ & - & $18.7 \pm 2.5$ & $12.39 \pm 1.60$ \\
\hline \multicolumn{7}{|l|}{ Height \% } \\
\hline $\mathrm{PIX}^{\circledR 113}$ & - & - & $122.3 \pm 12.3$ & $7.17 \pm 2.50$ & $13.6 \pm 2.0$ & - \\
\hline $\mathrm{PAX}^{\circledR} 18$ & - & - & - & $53.87 \pm 9.76$ & - & - \\
\hline
\end{tabular}




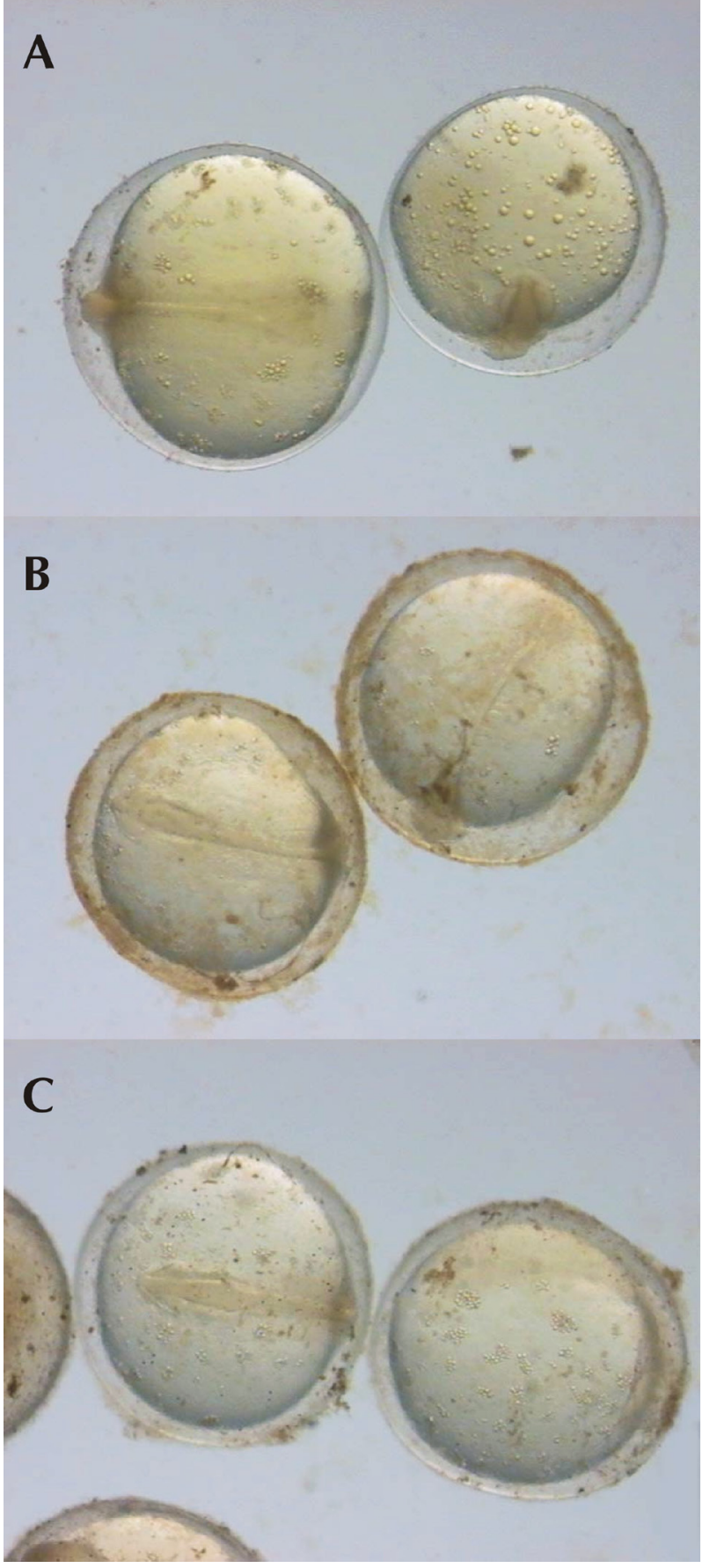

Fig. 1. Pike embryos at $52.0 \mathrm{D}^{\circ}-$ visible body outline of embryos: A - control sample, B - 1a PIX, C - 1b PAX

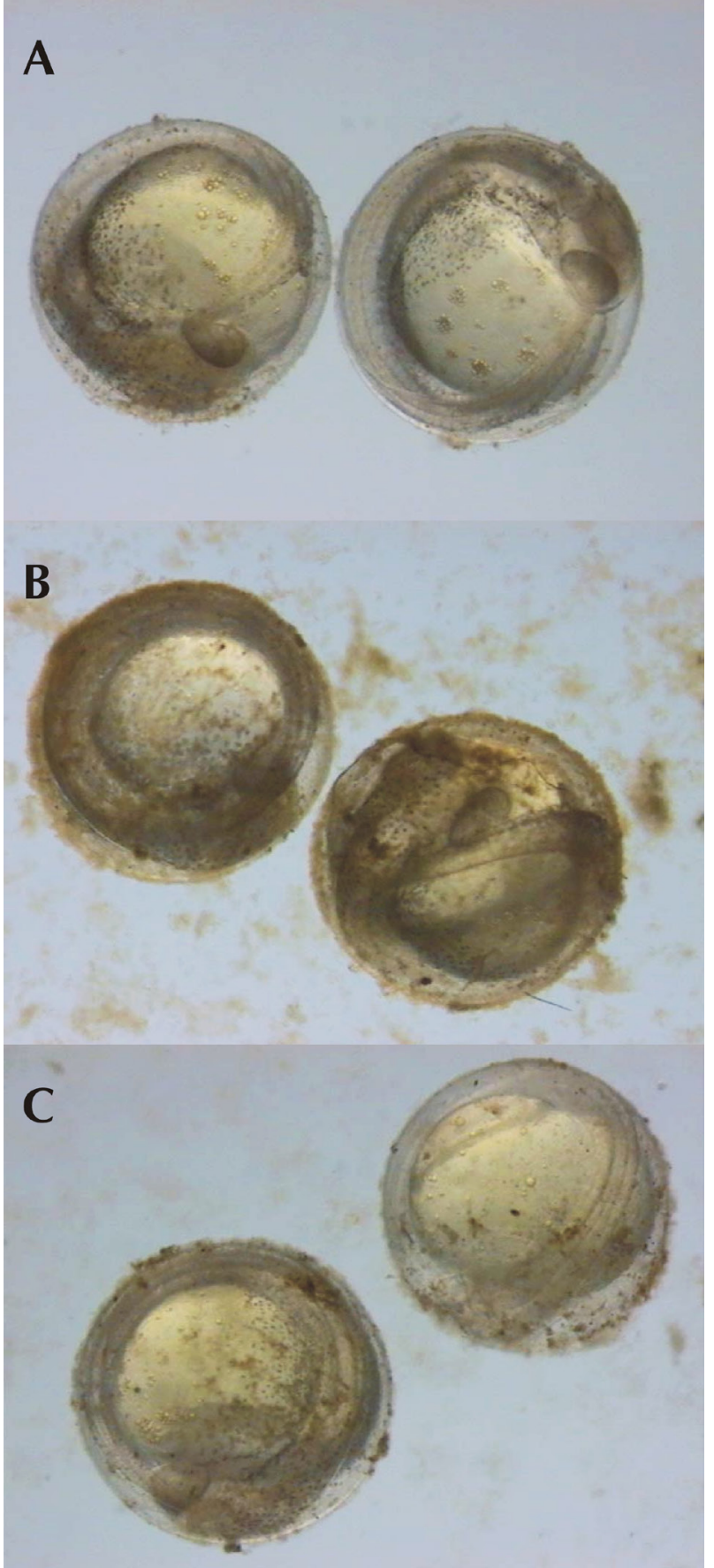

Fig. 2. Pike embryos at $110.0 \mathrm{D}^{\circ}$ - visible intense pigment in the eyes and on the bodies of embryos A - control sample, B - 1a PIX, C - 1b PAX

Table 4. Total length of larvae (average \pm standard deviation SD), percentage of embryos' survival rate, and malformed larvae in the studied experiment variants. Means denoted with identical superscripts are not significantly different at $\mathrm{p}=0.05$ (Duncan's multiple range test)

\begin{tabular}{lccccccc}
\hline & \multirow{2}{*}{$\mathrm{K}$} & \multicolumn{3}{c}{$\mathrm{PIX}^{\circledR} 113$} & \multicolumn{3}{c}{$\mathrm{PAX}^{\circledR} 18$} \\
\cline { 3 - 8 } & & $1 \mathrm{a}$ & $2 \mathrm{a}$ & $3 \mathrm{a}$ & $1 \mathrm{~b}$ & $2 \mathrm{~b}$ & $3 \mathrm{~b}$ \\
\hline Total length $(\mathrm{mm})$ (ANOVA $\mathrm{p}<0.01)$ & $8.99^{\mathrm{d}} \pm 0.33$ & $8.49^{\mathrm{b}} \pm 0.35$ & $8.38^{\mathrm{a}} \pm 0.28$ & $9.02^{\mathrm{d}} \pm 0.29$ & $8.45^{\mathrm{b}} \pm 0.38$ & $8.52^{\mathrm{b}} \pm 0.37$ & $9.16^{\mathrm{d}} \pm 0.31$ \\
\hline \% survival & 80.0 & 75.0 & 74.0 & 75.0 & 73.5 & 72.0 & 74.0 \\
\hline \% malformed larvae & 3.8 & 9.7 & 7.4 & 7.1 & 10.0 & 8.0 & 7.2 \\
\hline
\end{tabular}


stages of embryogenesis was 2-2.5 times higher (Table 4, Fig. 3).

The abnormalities in the larvae were diversified, including body deformations of "C-shaped" larvae, abnormal axial spinal curvature and scoliosis, as well as malformation in the case of so-called conjoined twins (Fig. 3). The highest number of conjoined twins hatched in the samples in which the eggs had been exposed to the effect of the coagulants, i.e. samples 1a and $1 b$.

\section{Discussion}

Hydrochemical studies of water from the Lake Przybiernów showed that the water used in the experiment was characterized by quality parameters that were favourable for the ichthyofauna inhabiting the lake. The recorded water $\mathrm{pH}$, combined with a high main ion content and total alkalinity exceeding 2.8 mval $\mathrm{dm}^{-3}$ allowed the conclusion to be drawn that the studied water was resistant to acidification, similarly to what was reported about the waters of some other lakes of Western Pomerania (including Lake Przybiernów) by Tórz et al. (2003), Tórz and Kubiak (2003), Nędzarek et al. (2011) and Tański et al. (2012). The recorded concentrations of nitrogen and phosphorus indicated high fertility of the water. According to Meybeck (1982), TIN concentrations in waters that had not been subjected to anthropopressure amounted to $0.120 \mathrm{mg} \mathrm{N} \mathrm{dm}^{-3}$, whereas in our study the TIN concentrations were six times higher (Table 1). TRP concentrations were also typical for water bodies on the borderline between eutrophy and hypertrophy (Zdanowski 1982). Conductivity and main ion concentrations were typical for waters characterized by moderate mineralization (Wetzel 2001).

The application of coagulants in the experimental research resulted in a drop in phosphorus and organic matter concentrations as well as in the precipitation of a solution that developed a layer with lowered $\mathrm{pH}$ as it was settling. Such phenomena are not uncommon as a result of applying coagulants for lake recultivation. For instance, Gawrońska et al. (2002) reported that phosphorus concentration decreased over twice as much under the influence of coagulants, which was mainly connected with the reduction in mineral phosphorus; the most severe reduction in phosphorus concentrations was observed in the waters of the epilimnion and metalimnion. A reduction in organic matter content was also noted.

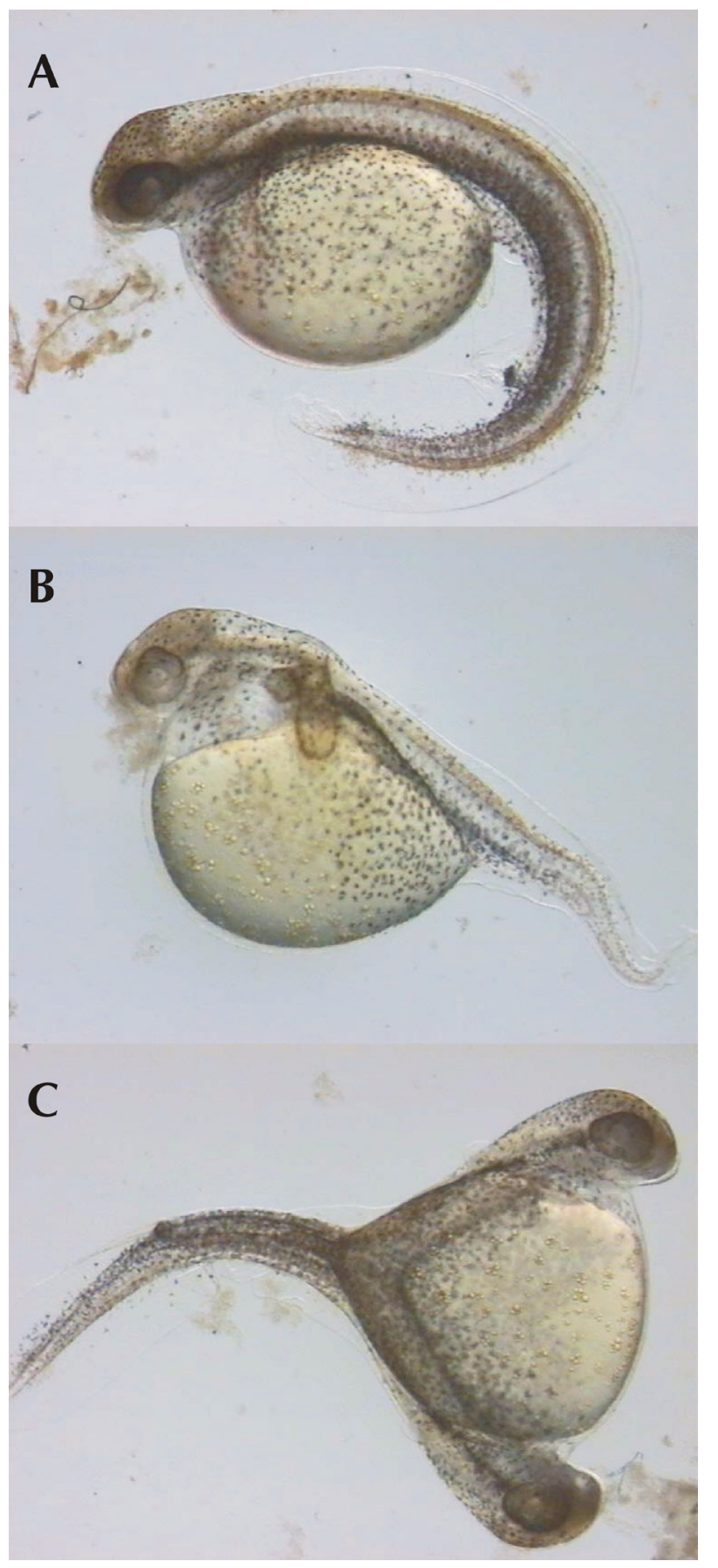

Fig. 3. Body deformations of pike larvae (A, B) and body malformations $(\mathrm{C})$ in variants $1 \mathrm{a}$ and $1 \mathrm{~b}$

The lowering of water $\mathrm{pH}$ noted in our study due to the effect of applied coagulants was typical for them; however, they acidified the aquatic environment to a lesser degree than other, alternative precipitating substances (Ito et al. 2000; Konieczny et al. 2007; Łopata et al. 2007; Piasecki and Zacharzewski 2010). 
The results of the conducted studies into the effect of PIX ${ }^{\circledR} 113$ and PAX 18 coagulants on developing embryos at respective stages of embryogenesis (blastopore closure, inoculation, and the beginning of hatching) showed that the impact of the coagulants varied depending on how advanced the development of the embryos was. It was noted that the aggregates forming while the coagulants were falling down as they were being dosed out into the water had a less and less diverse effect on the embryos as they were developing and growing, meaning that the percentage of healthy hatched larvae was increasing.

It was observed that the addition of coagulant doses to water at the stage when the eggs were approaching the end of the gastrulation process (development of the germinal epithelium - samples 1a and $1 \mathrm{~b}$ ) and the outline of the body of an embryo was visible, resulted in the occurrence of the highest number of body deformations and also the occurrence of malformation. This was connected with the fact that that stage of embryogenesis was a critical one for embryo development and was characterized by a heightened sensitivity of the developing embryos to unfavourable external factors (Wilkońska 1998). The suspension that was formed as a result of phosphates and organic compounds being bound by aluminium and iron coagulants settled on the surface of eggs and hindered oxygen access to their interiors as well as the excretion of metabolites; this had an impact on the important processes of organogenesis taking place inside the eggs at the time. The amount of the suspension (TSS) formed as the result of the coagulant application grew up to 10.1 (PIX ${ }^{\oplus} 113$ ) and $18.5 \mathrm{mg}$ $\mathrm{dm}^{-3}$ (PAX ${ }^{\circledR} 18$ ). Clinging to the outer egg membrane, the suspension provided an excellent growth medium for mould, whose development caused additional egg losses (Fig. 4).

The studies conducted by Bonisławska et al. (2011) revealed that a concentration of the total suspension in water exceeding $20 \mathrm{mg} \mathrm{dm}^{-3}$ had an adverse effect on the pike embryogenesis. It resulted in a drop in the percentage of fertilized eggs, reduced the percentage of healthy larvae hatched from the eggs, and the larvae were shorter and had a larger yolk sac. However, it should be noted that the studies in question focused on the suspension naturally occurring in water (Bonisławska et al. 2011), and not the suspension created as a result of coagulant application.

Similar dependencies with respect to the effect of coagulants on developing embryos were observed in the case when the coagulants were dosed out into the water at the stage of inoculation.

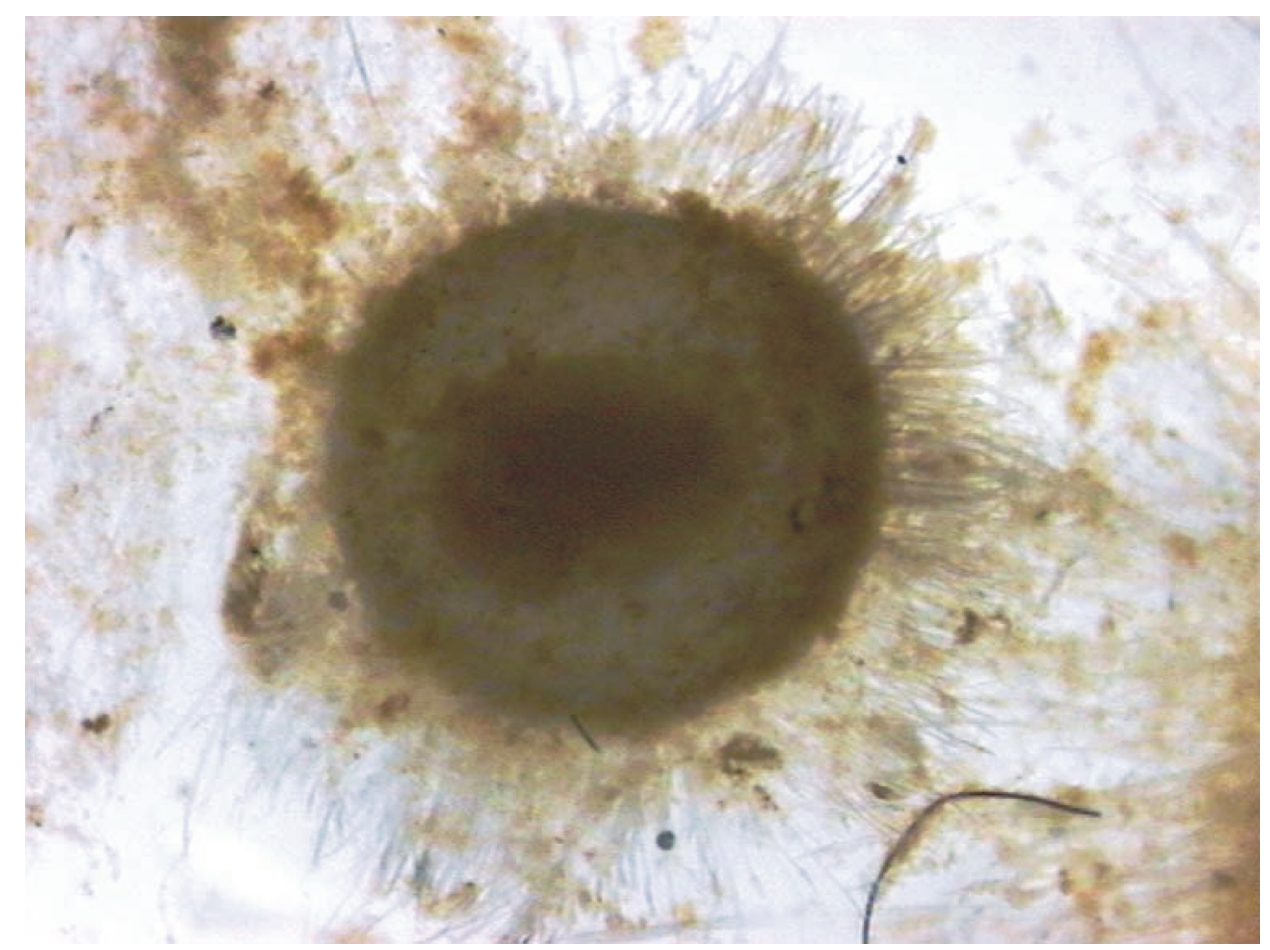

Fig. 4. A dead pike egg covered with mould hyphae 
In the samples in which the coagulants were applied at the first and second stage of embryogenesis (blastopore closure, inoculation), a slowing down of the embryonic development was observed resulting from a hindered gas exchange between the embryos and the external environment. As a result, individuals from samples $1 \mathrm{a}, 1 \mathrm{~b}$ and $2 \mathrm{a}, 2 \mathrm{~b}$ took longer to be ready to function independently in the environment and thus hatched later than the individuals from the control sample and samples $3 \mathrm{a}$ and $3 \mathrm{~b}$. Furthermore, once they hatched, the individuals from samples $1 \mathrm{a}, 1 \mathrm{~b}$ and $2 \mathrm{a}, 2 \mathrm{~b}$ were characterized by shorter body lengths in comparison to the individuals from the other samples.

The application of the coagulants at the time when the larvae began hatching resulted in the quickening of hatching. On the one hand, it was due to the fact that the suspension that formed as a result of the impact of PIX 113 and PAX 18 caused a drop in the concentration of the oxygen dissolved in water in the layer covering the eggs, which were viscous because of the phytophilous character of spawning (Tański et al. 2000). Thus, the embryos that were ready to survive independently in the environment started the process of hatching in order to free themselves of the inconvenient conditions inside the eggs. On the other hand, in the suspension layer there was a change in the $\mathrm{pH}$ value in comparison to the water layer above the suspension; the difference amounted to 0.56 for PIX 113 and 0.40 for PAX 18 . Such a small difference can affect the course of hatching since there are various optimal $\mathrm{pH}$ values for maximum proteolytic activity of the hatching enzyme in particular fish species (Yamagami 1973; DiMichele and Taylor 1981). Only the proper amount of such an enzyme, properly distributed, can initialize the digestion of the outer membrane of an egg, lowering its resistance and leading to actual larvae hatching. The research conducted by Ostaszewska (1998) into the enzyme triggering of the hatching of the Cyprinidae indicated that the process of hatching was delayed when the $\mathrm{pH}$ value of water deviated from the optimal value.

In the studies conducted by Bonisławska et al. (2012), in which pike eggs, directly after fertilization were subjected to the influence of the coagulants PIX $^{\circledR} 113$ and PAX ${ }^{\circledR} 18$, also in the concentration of 50.0 $\mathrm{mg} \mathrm{dm}{ }^{-3}$, a very serious drop in embryo survival rate was observed (even by $20 \%$ ), and the rate of occurrence of body deformations among hatched individuals grew over four times. In the present study, the drop in embryo survival rate ranged between 5.0\% and
$8.0 \%$, and the percentage of body deformations was only over two and a half times higher in the samples with the coagulants.

Summing up the above facts it can be assumed that in order to avoid excessive losses in the course of embryonic development of pike, the time of coagulant addition to water should be delayed so as not to coincide with the time of pike spawning which, depending on thermal conditions, takes place between the beginning of March and the end of April.

\section{References}

[APHA] American Public Health Association, 1995, Standard Methods for Examination of Water and Wastewater, APHA-AWWA-WEF, Washington, p. 1200.

Bonisławska M., Formicki K., Smaruj I., Szulc J., 2011, Total suspended solids in surface waters versus embryonic development of pike (Esox lucius L.), EJPAU 14(1): \#07 http://www.ejpau.media.pl/volume14/issue1/art-07. $\underline{\mathrm{html}}$

Bonisławska M., Tański A., Nędzarek A., Tórz A., 2012. Effect of the coagulants PAX and PIX on the embryonic development of pike (Esox lucius L.), Limnol. Rev. 12(3): 125-132.

DiMichele L., Taylor M.H., 1981, The mechanism of hatching in Fundulus heteroclitus: development and physiology, J. Exp. Zool., 217: 73-79.

Gawrońska H., Lossow K., Grochowska J., 2002, Influence of the aluminium coagulant PAX on the aquatic environment of Lake Długie in Olsztyn, Limnol. Rev. 2: 121-130.

Gawrońska H., Brzozowska R., 2002, Influence of the PAX coagulant application on internal loading in Lake Długie, Limnol. Rev. 2: 111-119.

Gawrońska H., Brzozowska R., Grochowska J, Lossow K., 2001, Effectiveness of PAX and PIX coagulants in phosphorus reduction in a lake - laboratory experiments, Limnol. Rev. 1: 73-82.

Ito A., Umita T., Lizawa J., Takachi T., Morinaga K., 2000, Removal of heavy metals from anaerobically digested sewage sludge by a new chemical method using ferric sulphate, Water Res. 34(3): 751-758.

Konieczny K., Bodzek M., Kopeć A., Szczepanek A., 2007, Coagulation - submerged membrane system for NOM removal from water, Pol. J. Environ. Stud. 14(4): 563-569.

Lelková E., Rulík M., Hekera P., Dobiáš P., Dolejš P., Borovičková M., Poulíčková A., 2008, The influence of the coagulant PAX-18 on Planktothrix agardhii bloom in a shallow eutrophic fishpond, Fottea 8(2): 147-154.

Łopata M., Gawrońska H., Brzozowska R., 2007, Comparison of effectiveness of aluminium and lantan coagulants in phosphorus inactivation, Limnol. Rev. 7(4): 247-253.

Meybeck M., 1982, Carbon, nitrogen and phosphorus transport by world rivers, Am. J. Sci. 282: 401-450. 
Nędzarek A., Tórz A., Kubiak J., Machula S., 2011, Habitat conditions for the ichthyofauna in anthropogenic Szmaragdowe Lake (Szczecin, Poland) in 2009-2010, [in:] Jankun M., Furgała-Selezniow G., Woźniak M., Wiśniewska A.M. (eds), Fish management in a variable water environment, Agencja Wyd. "Argi” SC R. Błaszak, P. Pacholec, J. Prorok, Olsztyn: 193-200.

Ostaszewska T., 1998, Development of unicellular hatching glands in carp (Cyprinus carpio L.), Ann Warsaw Agricult. Univ. SGGW-AR, Anim. Sci. 34:19-28.

Piasecki W.G., Zacharzewski D., 2010, Influence of coagulants used for lake restoration on Daphnia magna Straus (Crustacea, Cladocera), Baltic Coastal Zone 14: 49-56.

Pizarro J., Belzile N., Filella M., Leppard G.G., Nègre J-C., Perret D., Buffle J., 1995, Coagulation/sedimentation of submicron particles in a eutrophic lake, Water Res. 29(2): 617-632.

Podsiadłowski S., 2008, Methods of precise phosphorus inactivation in lake waters, Limnol. Rev. 8(1-2): 51-56.

Wilkońska H., 1998, Okres krytyczny w rozwoju (A critical period in the development), [in:] Szczerbowski J.A. (ed.), Encyklopedia rybacko-wędkarska (Fishery-Angling Encyclopaedia), Wyd. IRS Olsztyn, Olsztyn: 226 (in Polish).

Tandyrak R., 2002, Influence of lake restoration by the phosphorus inactivation method on the content of organic matter and phosphorus in lake bottom sediments, Limnol. Rev. 2: 399-406.

Tandyrak R., Lossow K., Gawrońska H., 2001, Long-term changes of environmental conditions in a lake restored by phosphorus inactivation, Limnol. Rev. 1: 263-270.
Tański A., Korzelecka A., Bonisławska M., Winnicki A., Formicki K., 2000, New data on morphomechanical changes during embryogenesis of pike (Esox lucius L), Folia Univ. Agric. Stetin. 214 Piscaria 27: 207-214.

Tański A., Brysiewicz A., Tórz A., Wesołowski P., 2012, Struktura połowów w jeziorze Przybiernowskim (woj. zachodniopomorskie) na tle panujących warunków hydrochemicznych (The structure of fish catches in Lake Przybiernowskie (West Pomeranian Voivodeship) in relation to hydrochemical conditions), Woda-ŚrodowiskoObszary Wiejskie 12(1): 193-208 (in Polish).

Tórz A., Kubiak J., 2003, Hydrochemical conditions in lakes of river Grzybnica catchment (Lakes: Ostrowo, Piaski, Przybiernowskie) in 1980-1997, Acta Sci. Pol. Piscaria 2(2): 117-128.

Tórz A., Kubiak J., Chojnacki J., 2003, Assessment of Lake Miedwie water quality in 1998-2001, Acta Sci. Pol. Piscaria 2(1): 279-290.

Wetzel R.G., 2001, Limnology: Lake and River Ecosystems, Elsevier, San Diego, California, p. 1006.

Wesołowski P., Pawlos D., Bonisławska M., 2010, Wybrane parametry jakości wód jeziora Resko Górne w warunkach ich napowietrzania (Selected parameters of water quality in aerated lake Resko Górne), WodaŚrodowisko-Obszary Wiejskie 10(4): 281-293 (in Polish).

Yamagami K., 1973, Some enzymological properties of a hatching enzyme (chorionase) isolated from the freshwater teleost, Oryzias latipes, Comp. Bio-chem. Physiol. B 46(3) 603-616.

Zdanowski B., 1982, Variability of nitrogen and phosphorus contents and lake eutrophication, Pol. Arch. Hydrobiol. 29(3-4): 541-597. 